\title{
AMOS BRONSON ALCOTT AND SOUTHEAST IOWA
}

\author{
By Dr. Louis A. Haselmayer \\ Iowa Wesleyan College, Mt. Pleasant, Iowa
}

A fascinating but baffling personality was Amos Bronson Alcott (1799-1888). Born in Connecticut and receiving little formal education, he began life as an itinerant pedlar. Although he soon abandoned itinerant merchandising, he devoted his life to peddling ideas. After settling in Boston and its environs, he was associated with leaders of the Transcendentalist Movement - Nathaniel Hawthorne, Ralph Waldo Emerson, Margaret Fuller and Henry David Thoreau. His published works are meagre in number and insignificant in content, but his correspondance and voluminous journals bear eloquent testimony to his role as an intellectual catalyst in the lives of many important persons.

A rebel and non-conformist in everything from religion to education, Alcott formed the Temple School in Boston where he introduced advanced methods of pedagogy, the Utopian community of Fruitlands, and the Concord School of Philosophy. Not least among his achievements was his family from which came his daughter, Louisa May Alcott, the author of a series of widely read children's books and family novels.

In spite of his New England roots and advanced age, Alcott joined the lecture movement throughout the west which had such vital impact after the Civil War. Emerson, Alcott and many other writers appeared in a host of communities which were culture-hungry. Alcott's specialty was the Conversazione, a kind of lecture combined with discussion. The favorite topics were religion and religious thinkers, New England authors, and general ethical themes. The emphasis in these talks, judging from the printed versions or newspaper accounts, was high thinking and moral uplift. From 1853 to 1882, Alcott was engaged in ten conversational tours of the West. ${ }^{1}$ Among

${ }^{1}$ Odell Shepard, Pedlar's Progress: The Life of Bronson Alcott (Boston; Little, Brown, 1937), p. 485. 


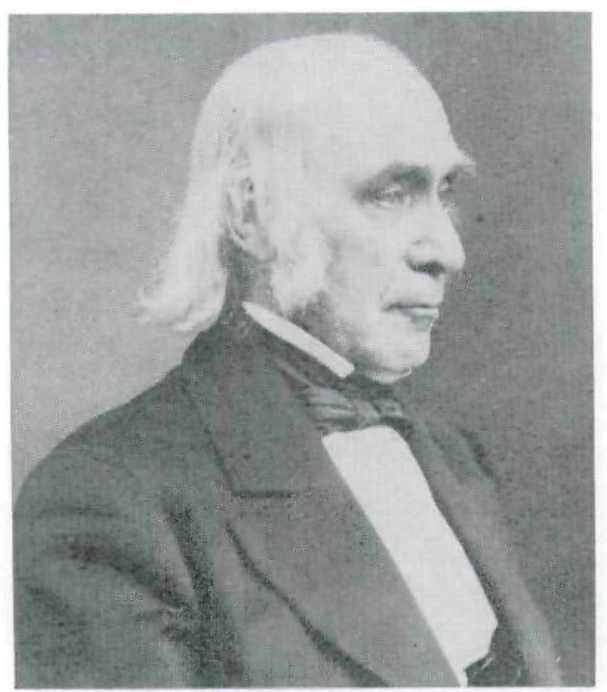

Amos Bronson Alcott

his most famous circuits were four visits of varying length to Iowa in 1870-1871; 1872-1873; 1874-1875 and 1881. These four tours have been the subject of historical investigation and a good amount of material has been published. ${ }^{2}$

The previous study, however, was limited almost entirely to Alcott's visits in north and northeastern Iowa. Except for one slight reference to stops in Mt. Pleasant and Burlington in 1881, the account fails to do justice to that visit and omits any reference to a more extended sojourn in 1873 to Mt. Pleasant, Burlington and Keokuk. ${ }^{3}$

These trips to southeast Iowa were of great interest because of their impact upon the communities. Especially vital was Alcott's influence in Mt. Pleasant because he entered into a

${ }^{2}$ Hubert H. Hoeltje, "Some Iowa Lectures and Conversations of Amos Bronson Alcott," Iowa Journal of History and Politics, XXIX, 3 (July 1931). This is based upon Emerson and Alcott in Iowa with Notes on the History of Iowa Lecturing 1855-1885, State University of Iowa M. A. Thesis, 1926.

${ }^{3}$ Ibid., p. 390. The reference is based upon a diary entry which was reported to the author and there is no first hand examination of primary source material. 
pattern of cultural activity sponsored by a rather closeknit group of citizens. Concrete results developed such as the formation of the Ladies Library Association which eventually established the Mt. Pleasant Public Library. On the occasion of the dedication of the Public Library Building on February 22,1905 , the speaker linked this event to Alcott's visit of $1873 .{ }^{4}$ There was a definite tradition kept alive by this women's group for a quarter of a century that Bronson Alcott had been the "father-inspirer" for the Public Library. ${ }^{5}$

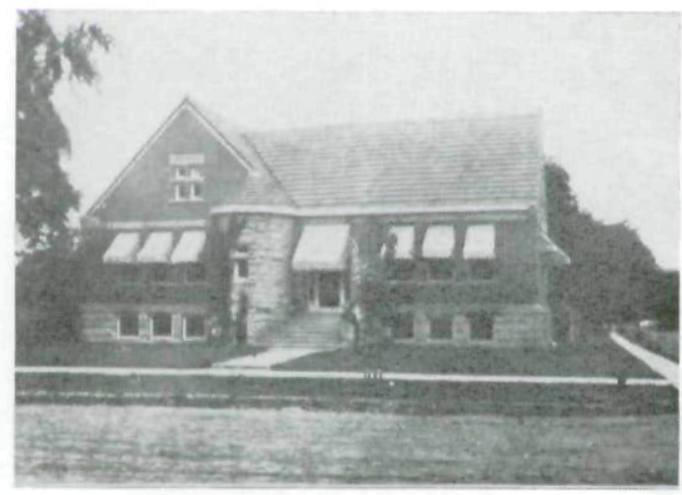

Mt. Pleasant Public Library.

Two visits to the area included a stay in 1873 in Mt. Pleasant from January 10-14; in Burlington from Januray 21-24 and in Keokuk from January 29-February 2. The visit of 1881 consisted of a two day stop in Mt. Pleasant on March 21-22, and, apparently, a brief visit to Burlington at the same time. There was considerable difference in the reception of Alcott in Mt. Pleasant and Keokuk as compared with that in Burlington. Definite factors in each community affected the intellectual climate.

${ }^{4}$ Mt. Pleasant Free Press, March 2, 1905. All Mt. Pleasant newspapers of this period are in the C. S. Rogers Collection at Iowa Wesleyan College.

${ }^{5} \mathrm{Cf}$. the manuscript and clipping a lbum, History of the Public Library of Mt. Pleasant and other allied cultural and educational activities from 1848-1905 when the modern history begins, compiled by Olive Cole Smith, in Mt. Pleasant Public Library. 


\section{MT. PLEASANT}

In 1873 Mt. Pleasant had about 4500 inhabitants (the 1875 Census listed 4563). But its size was offset by certain geographical features, a number of institutions and a remarkable group of citizens who were receptive to intellectual influences. By 1879 it was given the somewhat grandiose title of "Athens of Iowa."

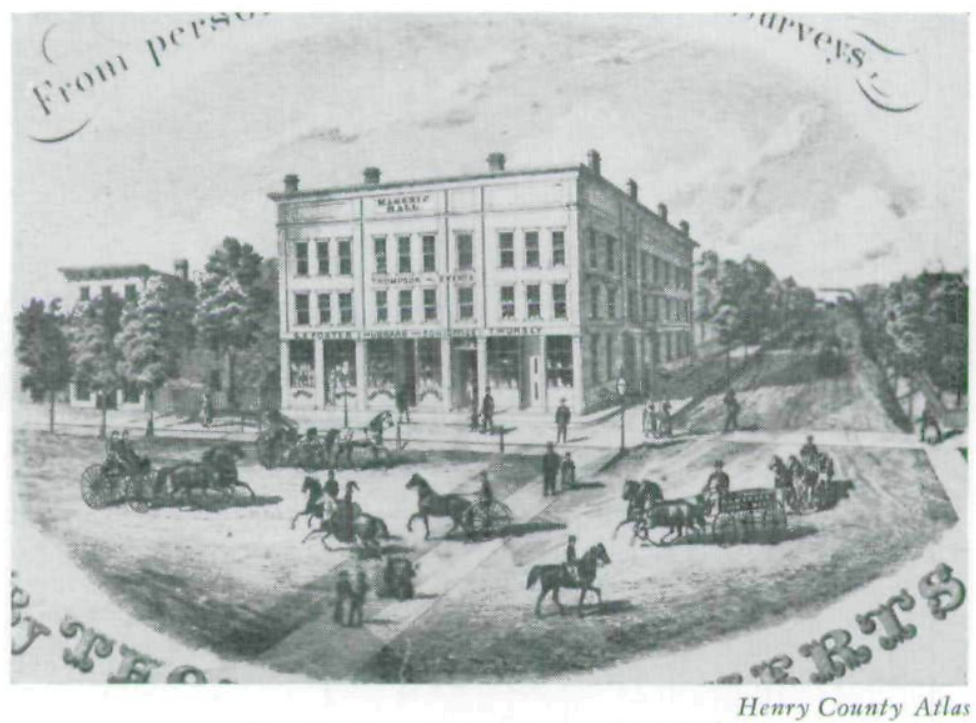

Mt. Pleasant street scene in the 1870's.

As the county seat of Henry County, it drew to its area men of legal training. A number of these became prominent in political affairs in the state and the nation. James Harlan, after serving in the United States Senate and Presidential Cabinet until 1873, lived in the community until his death in 1899. But there were others also who brought the community into a wide perspective of public affairs and ideas.

Mt. Pleasant was located on the main line from Chicago of the Burlington and Missouri River Railroad and had earlier been the termination point of the Burlington and Mount Pleasant Plank Road.

${ }^{6}$ The History of Henry County, Iowa (Chicago: Western Historical Company, 1879), p. 412. 
Located in Mt. Pleasant was Iowa Wesleyan University, founded in 1842 as the Mt. Pleasant Collegiate Institute. During the presidency of Senator James Harlan (1853-1855), it became affiliated with the Methodist Church. The University went through a precarious existence in the post-Civil War period, was small in enrollment and faculty and limited in building facilities. Various attempts to expand the university culminated in the 1870 's by the additions of departments

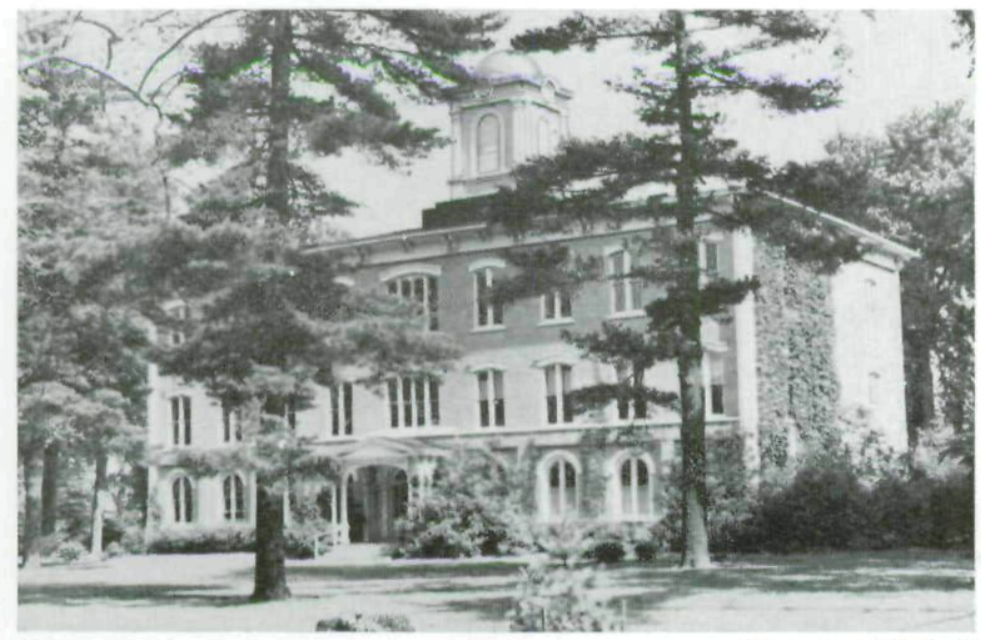

Iowa Wesleyan's “Old Main,” built in 1855 .

Photo by Will Dyall

of law, pharmacy and medicine. These departments drew upon the services of professional men in Mt. Pleasant who lectured at the University and created a link between the University and the community. Through this, the University was a factor in an atmosphere conducive to intellectual growth.

Mt. Pleasant was also the site of the Iowa State Hospital for the Insane. During the post-Civil War period, its superintendent and wife, Dr. and Mrs. Mark Ranney, were cultural leaders in the community. In 1870 Professor Alexander Rommel founded the Iowa Conservatory of Music which for many years provided the city with musical programs and attracted music students and recitalists. 


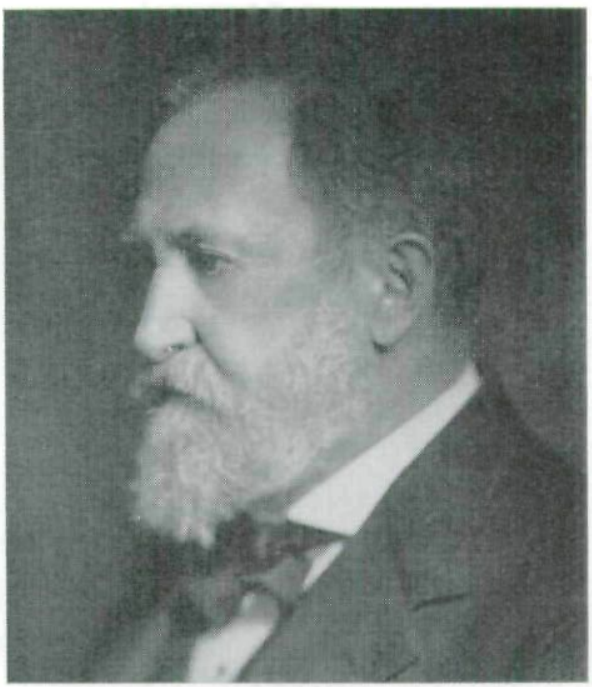

Professor Alexander Rommel

But even more important than the institutions and location was the influx during the 1850 's and 1860's of professional men, especially lawyers, doctors and journalists, who had been trained in the east and brought to the city a background of culture. In almost every instance, the wives of these men were college graduates or persons of taste and refinement who were active in the promotion of cultural programs. Through professional association, social contacts and marriages, these persons became intimately identified in corporate activities to stimulate their own intellectual lives and raise the tone of the community.

Those whose names appear most frequently in these connections were: The Rev'd Dr. and Mrs. William R. Cole; Mr. and Mrs. James A. Throop; Dr. and Mrs. Charles F. Marsh; Dr. and Mrs. W. S. Marsh; Mr. and Mrs. Henry Ambler; Miss Phoebe Leech Elliott; Dr. and Mrs. Mark Ranney; Dr. and Mrs. A. W. McClure; Miss Alice Bird, later Mrs. Washington I. Babb; Miss Myra Bird, later Mrs. John S. Woolson. Since names in themselves carry little illumination, a brief biographical account will reveal not only the background of these persons but also their personal and professional relationships. 
The dominant personality was the Rev'd Dr. William R. Cole. ${ }^{7}$ Born in Dearborn County, Indiana, he came with his family to Mt. Pleasant where he attended the local schools. A graduate of Lombard College in Galesburg, Illinois and the Harvard Divinity School, he served as a Unitarian minister in the Mt. Pleasant area from 1864-1874. For the remainder of his life, he managed the family business, Cole Brothers, manufacturers of pumps and lightning rods. These business connections extended from Iowa in to Nebraska, Kansas, Arkansas, Texas, Missouri and Indiana. To his educational background of considerable distinction was added a business acumen. In the autumn of 1857, he married Cordelia Throop of New York City who shared with him many cultural concerns. Dr. Cole was a leader in almost every civic activity for twenty years and was a generous contributor to the foundation of Das Deutsche Kollegium, the German Methodist Theological Seminary established in Mt. Pleasant in $1873 .^{8}$

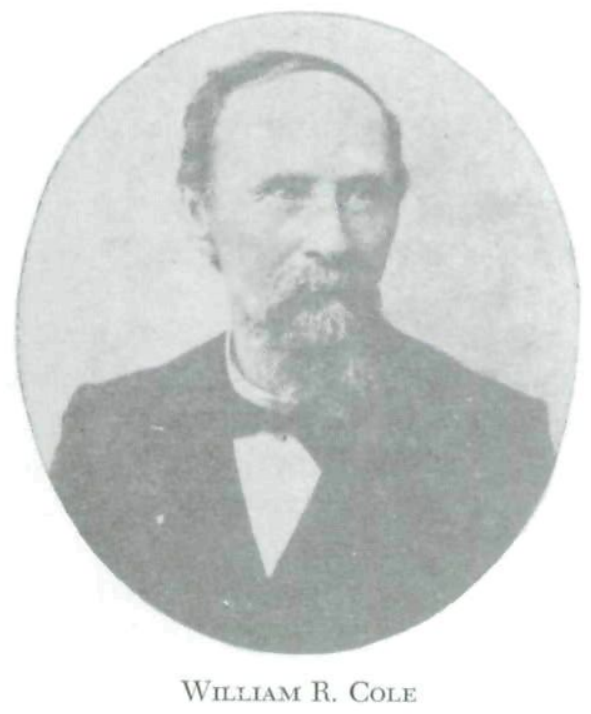

${ }^{7}$ The History of Henry County, Iowa, op.cit., p. 560; Biographical Review of Henry County, Iowa, (Chicago: Hebert Publishing Company, 1906 ), p. 708.

${ }^{8}$ Louis A. Haselmayer, "Das Deutsche Kollegium," Annals of Iowa, XXXV, No. 3 (Winter, 1960), p. 208. 
Cordelia Throop Cole had an alert interest in public affairs and literary matters. She was a leader of the first Reading Clubs and the Ladies Library Association. Her connection with this organization was continued by her daughter, Olive Cole Smith, whose manuscript album of the history of the Mt. Pleasant Public Library is a valuable document.

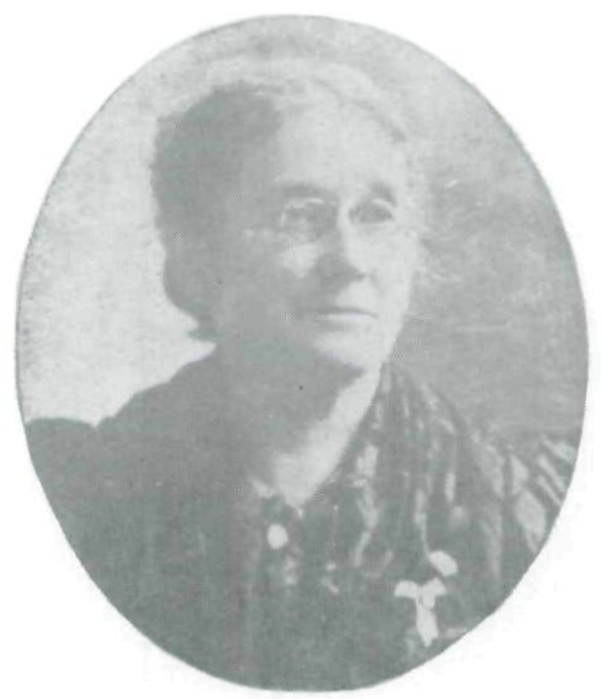

Cordelia Throop Cole

Mrs. J. A. Throop (Rowena Blake), born in Chenango, N.Y., married James A. Throop on April 7, 1858. ${ }^{9}$ James A. Throop was the brother of Mrs. William R. Cole and settled in Mt. Pleasant in December 1856 where he was associated with Cole Brothers for seven years. In June 1872, together with Edwin Van Cise, he bought the Free Press of which he was sole manager after 1877 . He was active on the school board, the city council and in the Universalist Church of Mt. Pleasant.

Dr. Charles F. Marsh, together with his brother Dr. W. S.

${ }^{9}$ The History of Henry County, Iowa, op.cit., p 584; Portrait and Biographical Album of Henry County, Iowa (Chicago: Acme Publishing Company, 1888), pp. 370-371. 
Marsh, was a local physician. He served from 1870-1872 as Professor of Pharmacy, Materia Medica and Medical Jurisprudence at Iowa Wesleyan University. ${ }^{10}$

Henry Ambler, born in Pennsylvania, settled in Mt. Pleasant in October 1856 in the practice of law, first with Theron Webb Woolson and later with his brother Richard Ambler. ${ }^{11}$ He was a member of the city council, practiced in the United States Supreme Court, was a Trustee of Iowa Wesleyan University (1859-1883) and Professor of Law of Real Property, Pleadings, Evidence and Equity Jurisprudence at the University (1858-1882). ${ }^{12}$ Among his six children active in literary matters was Penelope (Nellie) Ambler, later Mrs. W. H. Campbell of St. Joseph, Missouri, who was Preceptress and Professor of English Literature at Iowa Wesleyan University.

Phoebe Leech Elliott was the daughter of Dr. Charles Elliott, president of Iowa Wesleyan University for two terms

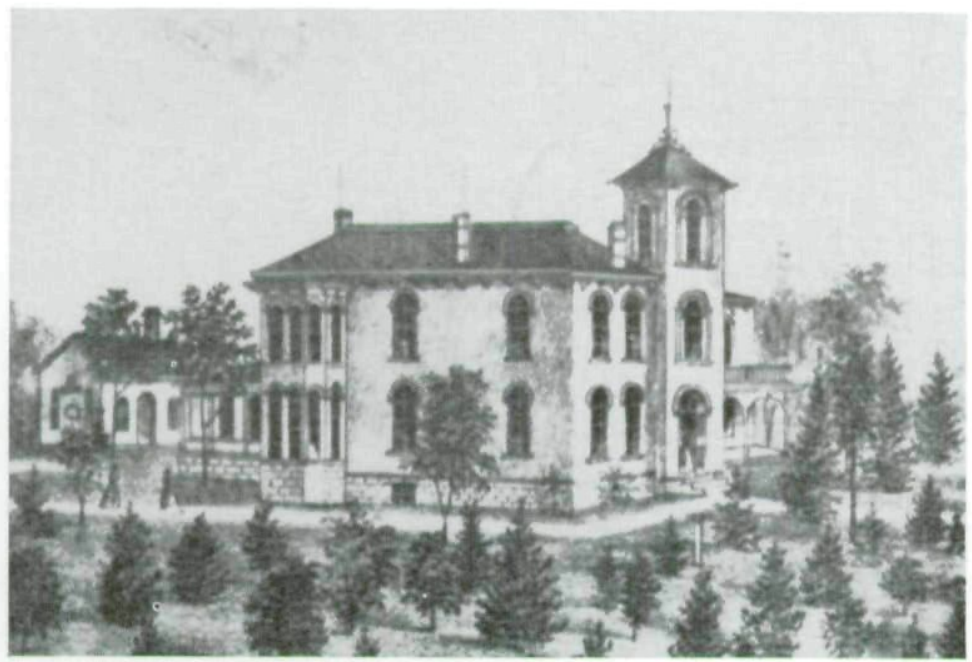

Residence of Henry Ambler, Mt. Pleasant, Iowa, 1870.

Henry County Atlas

${ }^{10}$ The History of Henry County, Iowa, op.cit., p. 575. Catalogues of Iowa Wesleyan University, 1870-1871; 1871-1872.

${ }^{11}$ The History of Henry County, Iowa, op.cit., p. 512, 557. Portrait and Biographical Album of Henry County, Iowa, op.cit., p. 369.

${ }^{12}$ The History and Alumni Record, Iowa Wesleyan College, 1842 1942 , p. $96,102$. 
(1857-1861; 1863-1866). ${ }^{13}$ An 1860 graduate of the University with the degree of Bachelor of English Literature, she served as a Trustee from $1875-1879 .{ }^{14}$

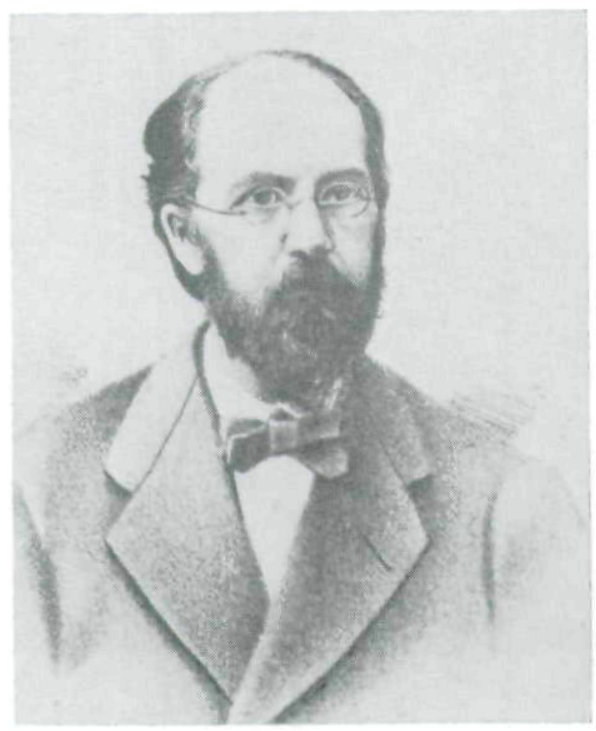

Dr. Mark Ranney

Dr. Mark Ranney, born in Vermont and an 1849 graduate of the Vermont Medical College, engaged in medical practice in Rhode Island and Boston until he settled in Mt. Pleasant in 1869 as Superintendent of the Iowa State Hospital for the Insane. ${ }^{15}$ He held this position until 1873 when he went to Wisconsin for two years and then returned to Mt. Pleasant. Mrs. Mark Ranney, the former Martha Sawyer of Sterling, Massachusetts, was academically trained and served as Matron of the State Hospital for a time. Dr. Ranney's intellectual interests reached far beyond the field of medicine and his extensive private library of the classics, literature, history, art appreciation, in both rare and current editions, remains intact today at the State University of Iowa as part of the Special Collections.

${ }^{13}$ The History and Alumni Record, op.cit., p. 122

${ }^{14}$ Ibid., p. 97.

${ }^{15}$ The History of Henry County, Iowa., op.cit., p. 579. 


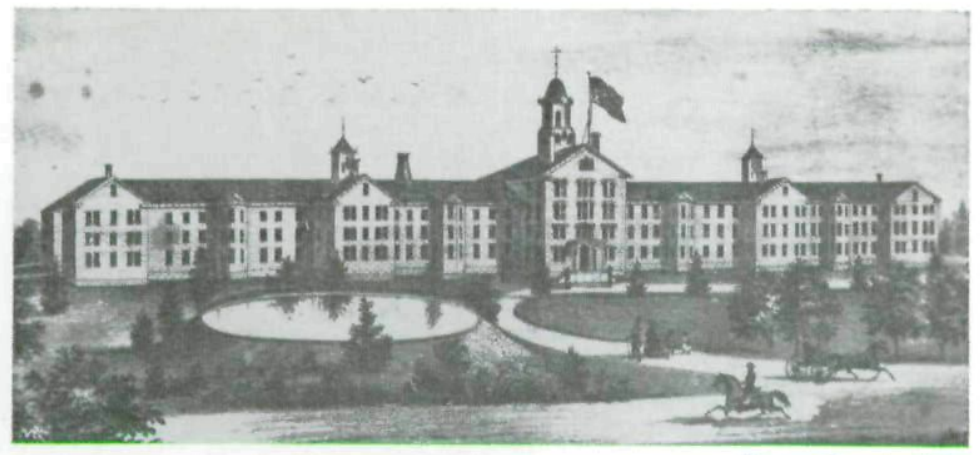

Iowa Hospital for the Insane.

Henry County Atlas

Dr. and Mrs. A. W. McClure represent a marriage of a local girl and a man from the east. Emily Porter McClure was the daughter of Colonel A. B. Porter, one of the oldest settlers of Henry County. In 1860 she married Andrew W. McClure of Lebanon, Ohio, who was an 1853 graduate of the Ohio Medical College in Cincinnati and opened practice in Mt. Pleasant in $1856 .{ }^{16}$ After serving as a surgeon with the

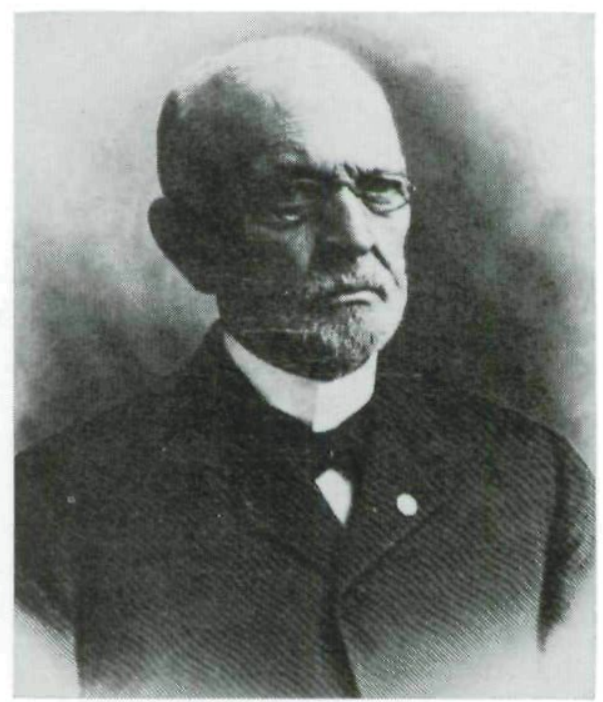

Dr. A. W. McCluRE

${ }^{16}$ The History of Henry County, Iowa. op.cit., p. 572. 
4th Iowa Calvary, he returned to Mt. Pleasant and became associated with the Wheel Scraper Company, one of the local industries. He was a Trustee of the State Hospital for ten years and in 1872 joined the faculty of Iowa Wesleyan University as Lecturer in Anatomy. ${ }^{17}$

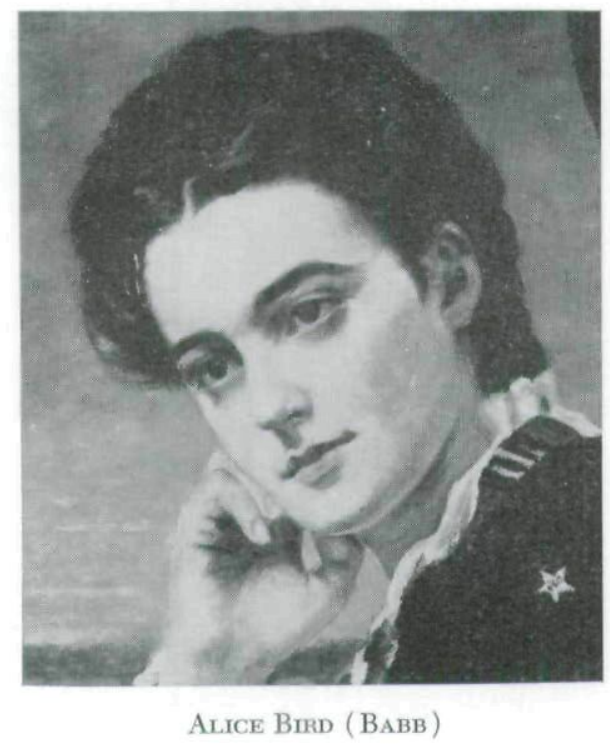

Alice Bird, a native of Mt. Pleasant, received both A.B. and A.M. degrees from Iowa Wesleyan University. During the academic year of 1871-1872 she served as Professor of Latin, Greek and Elocution at the University. ${ }^{18}$ In 1873 she married Washington I. Babb of Mt. Pleasant. She was one of the seven founders of the P.E.O. Sisterhood, today a national noncolegiate women's sorority, particularly interested in the education of women.

Myra Bird, the sister of Alice Bird, married John S. Woolson. ${ }^{19} \mathrm{He}$ was born in Erie County, N.Y., but received both

${ }^{17}$ History and Alumni Record, op.cit., p. 103. Catalogue, Iowa Wesleyan University, 1879-1880, p. 7.

${ }^{18}$ History and Alumni Record, op.cit., p. 103, 127.

${ }^{19}$ History of Henry County, Iowa, op.cit., p. 588; History and Alumni Record, op.cit., p. 123, 327-328. 
A.B. and A.M. degrees from Iowa Wesleyan University. He read law with his father, enlisted in the Navy during the Civil War and was admitted to the bar in 1866. He served in the State Senate in 1875 and became Chairman of the State Board of Commissioners of Insanity in 1870. He married Myra

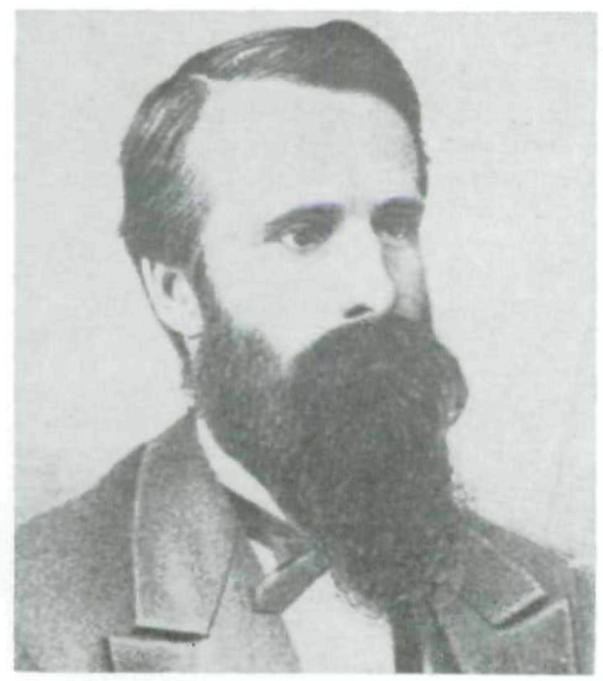

JoHn S. Woolson

Bird in 1867 who had likewise received A.B. and A.M. degrees from Iowa Wesleyan. She was long prominent in club activities and occasional newspaper journalism.

One vigorous community effort of this group of women was the attempt as early as 1866 to found a library and sponsor a series of visiting lecturers. ${ }^{20}$ The lectures were organized primarily to raise money for the library, but they also stimulated the aims of the group. Mt. Pleasant was swept into the orbit of the lecturing system. In 1866-1867, Theodore Tilton and Wendell Phillips appeared in the community; in 18671868, Josh Billings, the humorist; in 1868-1869, Petroleum V. Nashby, Theodore Tilton, Susan B. Anthony and Elizabeth Cady Stantan provided the course and in other years Carl Schurtz, Henry Ward Beecher, John C. Saxe and C. D. B.

${ }^{20}$ History of the Public Library of Mt. Pleasant, op.cit., p. 3. 
Mills. ${ }^{21}$ Leaders in reconstruction problems, professional humorists and woman suffrage chieftains were the popular drawing cards.

But this informal group needed greater organization and in December, 1877 a Ladies' Reading Circle was started and officers were elected. The newspaper account lists the women who will long be influential cultural leaders of Mt. Pleasant.

At a meeting of the ladies of the city last Friday evening, for the purpose of organizing a reading club, the following officers were chosen,-President, Mrs. W. R. Cole; Vice President, Mrs. Dr. Ranney; Secretary, Miss Phoebe Elliott. Readers for next evening: Mrs. J. A. Throop, Mrs. A. W. McClure. The next meeting will be held at the residence of Mrs. John S. Woolson, on next Saturday evening. All the ladies of Mt. Pleasant interested in this enterprise or literary culture in general, are earnestly requested to attend. By order of

Mrs. C. F. Marsh ${ }^{22}$ Pres. pro tem.

One of the first official acts of this group was the entertainment on a four day visit, one month later, of Amos Bronson Alcott, whose appearances in the community were chiefly in the homes of the members. ${ }^{23}$

Alcott arrived in Mt. Pleasant on Friday, January 10 and remained until Tuesday, January 14 at the home of Dr. and Mrs. William R. Cole. The Cole home on North White Street where Alcott stayed on this visit and again in 1881 is still occupied today as a residence. The conversazione topics chosen for the occasions were generally those which he used elsewhere on his Iowa tour of $1872-1873{ }^{24}$ The first was on "Character" and was given on Saturday evening at the home of Dr. and Mrs. W. S. Marsh. The second, on Monday evening, January 13, at the home of Dr. and Mrs. C. F. Marsh, was on the topic of "New England Authors." This was Alcott's most popular lecture because of his personal friendships with the writers. In a variety of versions it was delivered in Daven-

${ }^{21}$ Ibid., p. 3. Biographical Review of Henry County, Iowa, op.cit., p. 708 .

${ }^{22}$ Henry County Press, Friday, December 13, 1872.

${ }^{23} \mathrm{~A}$ full account of the visit with complete details appears in Henry County Press, Friday, January 17, 1873.

${ }^{24}$ Hoeltje, op.cit., p. 375,381 . 


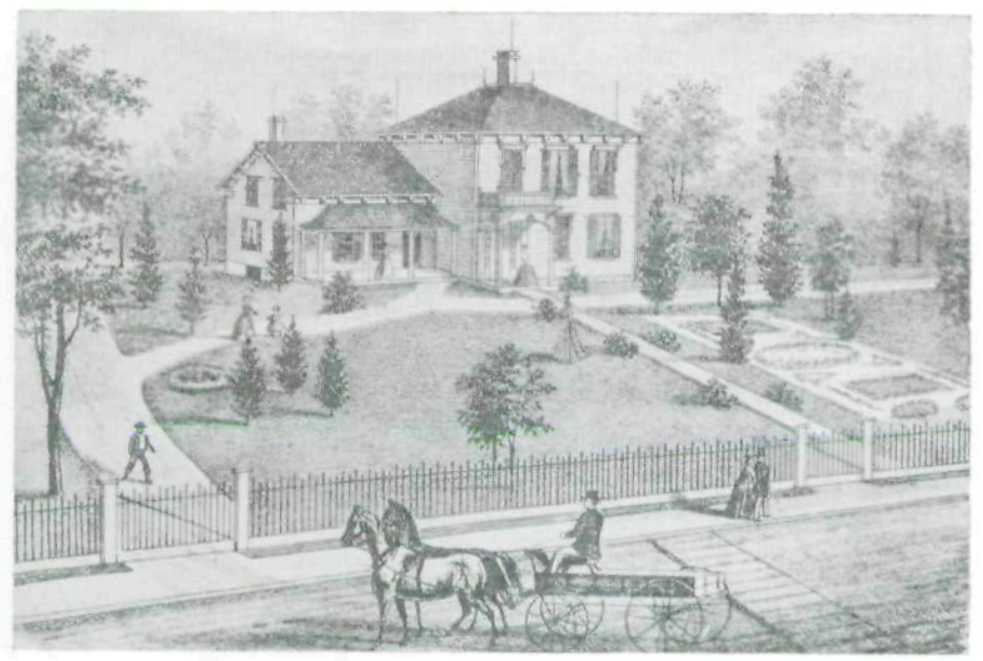

Residence of William R. Cole, Mt. Pleasant, 1870.

Henry County Atlas

port, Dubuque, Iowa City, Keokuk and Burlington. It gained extended newspaper coverage by the Iowa City Daily Press, the Davenport Daily Gazette and the Dubuque Heraid. ${ }^{25}$ On the same day, there was a tea in honor of Alcott at the home of Dr. and Mrs. William R. Cole. ${ }^{26}$

On Sunday, January 12, Alcott preached in the Chapel of Iowa Wesleyan University on "Character and Culture" and during the day on Monday, January 13, spoke to the faculty and student body on "How Certain Celebrated Authors Write Their Books," a re-worked version of "New England Authors." 27

The lectures on the New England writers were extremely popular. Alcott talked of the work and personalities of Emerson, Thoreau, Hawthorne, Channing, Whittier, Holmes, Longfellow, Lowell and Margaret Fuller. They were first hand glimpses into the work of these Transcendental and New England writers who were popular with cultivated readers at the time. The success of Louisa May Alcott's books, Little

${ }^{25}$ Ibid., p. 379.

${ }^{26}$ Henry County Press, January 17, 1873.

${ }^{27}$ Iowa Classic. Iowa Wesleyan University, III, No. 5, February 1873. 
Women and Old Fashioned Girl resulted in many questions about the daughter of the speaker. The rather stilted account in the University monthly magazine is a delightful sidelight.

He also gave a very interesting account of his daughter-Miss Alcott the author of "Little Women" ... . We shall be pleased to welcome him again, and will extend a cordial invitation to the author of "Little Women" to visit the University in any western tour she may contemplate. ${ }^{28}$

The community interest seemed to increase over the weekend for the newspaper states that "The attendance, particularly, on the second evening was good and the conversations a rare literary treat."

Four lecture appearances on three successive days was a rather heavy schedule and Alcott managed to visit the public schools as well. But even apart from the published reports, one can speculate on the impact of his dynamic personality during the visit. The fact that certain groups kept this visit alive in memory for twenty-five years is ample evidence of its widespread effect on those who met Alcott.

Immediate results were the increased impetus to the Ladies Reading Club and the formation of a similar evening organization for men as well as women.

The interest created in the subject by Mr. Alcott's conversations has led to the formation of a "Social Circle" in Mt. Pleasant-first meeting at the residence of Henry Ambler, Esq., on this Thursday evening. ${ }^{29}$

The gathering attracted an important body of citizens and a full program was planned.

A conversational club was organized in this place on Thursday evening, 16th inst., at the residence of Henry Ambler, Esq. Officers elected: H. Ambler, President; Mrs. C. T. Cole, Vice President; Dr. C. F. Marsh, Secretary. A permanent committee was selected whose duty it is to choose a leader for each evening of the meetings. Miss Allie Bird, Miss Celia Gillis and Mr. Chas. Pennington compose this committee. The next meeting was appointed for Thursday evening, Jan. 30th, at 7 o'clock at Dr. C. F. Marsh's. Rev. Wm. R. Cole appointed leader. $^{30}$

${ }^{28} \mathrm{Ibid}$.

${ }^{29}$ Henry County Press, Friday, January 17, 1873.

${ }^{30}$ Henry County Press, January 24, 1873. 
Both of these organizations functioned with regularity during the year and the topics of discussion ranged from "Modern Civilization" to "Mental Health." ${ }^{11}$ In addition to the original leaders, other persons soon became active including Mr. Washington I. Babb, Dr. Wellington Bird and Professor Alexander Rommel.

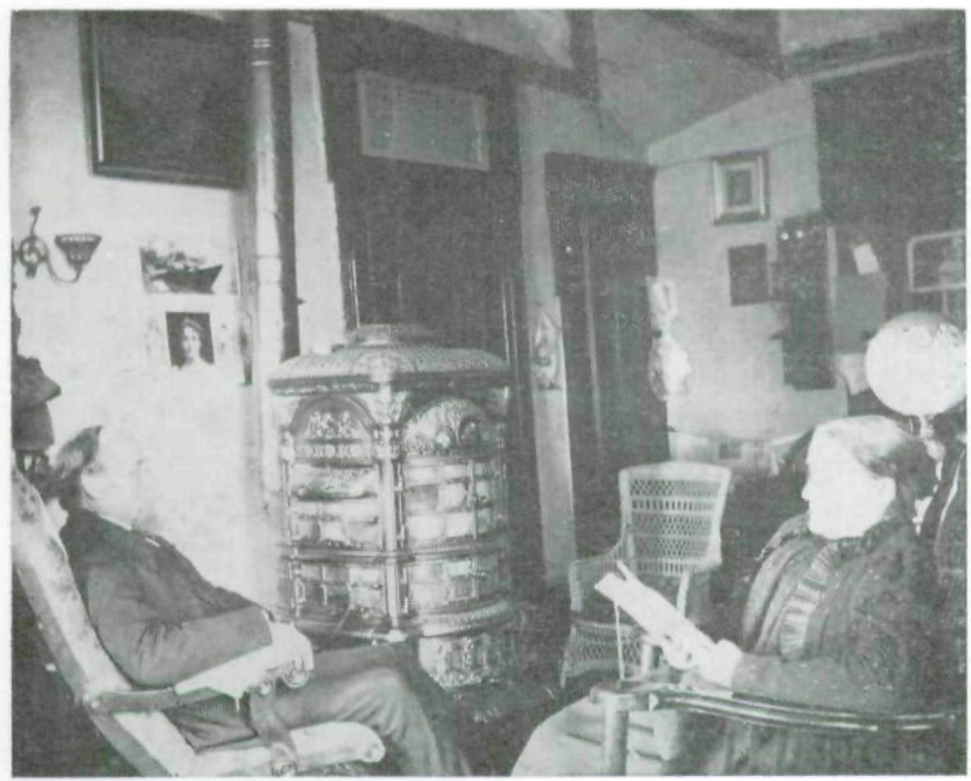

Courtesy Baron Crane

Mr. and Mrs. William Cole sitting in their parlor where Amos Bronson Alcott conducted several of his "Conversations."

The meetings of the evening club seem to have slacked off after the first eight months and there are few newspaper notices after that period. But the Ladies Reading Circle flourished until 1875 when it merged into the Ladies Library Association, an organization still in existence today. ${ }^{32}$ This organization incorporated with the sum of $\$ 360$ in the treas-

${ }^{31}$ For Ladies Reading Club, cf. Henry County Press, February 7, 14, 28; April 11, 25; May 9, 23, 30. For Conversation Club, cf. Henry County Press, February 7, 28; March 7, 14; April 11, 18; May 9, 16, 30; June 20.

${ }^{32}$ Biographical Review of Henry County, Iowa, op.cit., p. 708. 
ury and opened a canvass for $\$ 5000$ for books. The articles of incorporation include the names of the leaders: Miss Nellie E. Ambler, Mrs. W. S. Marsh, Mrs. C. T. Cole, Mrs. Alice L. Taylor, Mrs. M. W. Ranney, Mrs. C. S. Marsh, Mrs. A. C. Woolson, Miss Rachel Carney, Miss Emma L. Schwenker, Mrs. C. T. Marsh, Mrs. Belle A. Mansfield. ${ }^{33}$

The group kept in touch with Alcott for he wrote back to one person in Mt. Pleasant: "The good account which you give concerning your intellectual recreations tell well for Mt. Pleasant. It is highly gratifying if the finely told history of the Friends in Council, proved so inspiring to your reading and conversational circles."

In 1881 Bronson Alcott made his final Iowa tour at the age of 82. His return to Mt. Pleasant as the guest of Dr. and Mrs. William R. Cole included two conversations at the Cole home on the evenings of Tuesday, March 21 and Wednesday, March 22. Newspaper notices of the visit appeared in both the Free Press and the Mt. Pleasant Journal. ${ }^{35}$ But of even

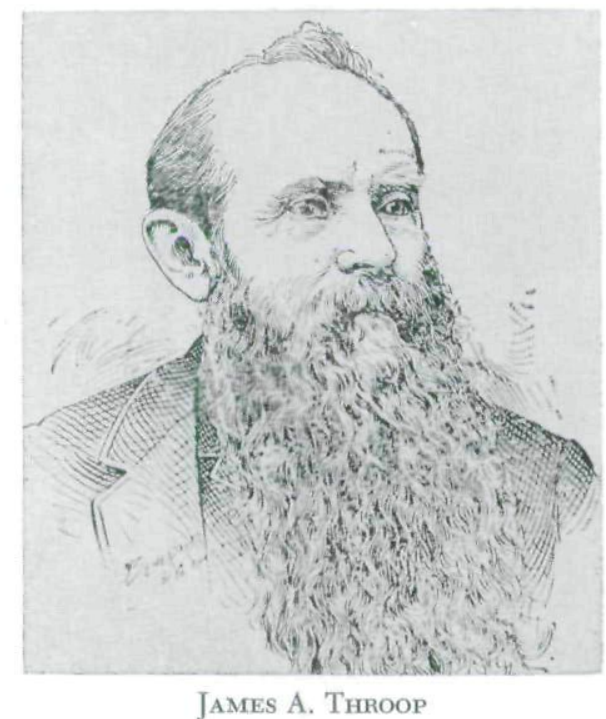

${ }^{33}$ The History of Henry County, Iowa, op.cit., p. 532.

${ }^{34}$ Quoted in the Address at the Dedication of the Public Library Building, Mt. Pleasant Free Press, March 2, 1905, pp. 170-171.

${ }^{35}$ Free Press, March 31, 1881; Mt. Pleasant Journal, March 29, 1881. 
greater importance than the news items were the two extensive summaries of the evenings and the lectures in both newspapers. That in the Free Press, edited by James A. Throop, the brother of Mrs. William R. Cole, is of sufficient color to deserve generous quotation.

Two of the pleasantest of parlor entertainments were held at the residence of Rev. W. R. Cole on Tuesday and Wednesday evenings of the last week.

On the first occasion a little circle of about forty friends was informally invited by the host and hostess-who know so well how to do these charming social things-to come and spend an evening with their honored guest, Mr. A. Bronson Alcott, and to be led by him in a conversation on the "Concord Philosophers." He brought forward, during the evening, Mr. Emerson, Mr. Hawthorne, Mr. Henry Thoreau, Margaret Fuller, and Louisa M. Alcott, forming such sketches as can be drawn only by one with an intimate acquaintance with the characters that he portrays. He presented Mr. Emerson as the theologian, the philosopher, the poet and the neighbor, and always as a man of "light"-pure in life and earnest in purpose. He gave a most interesting account of the Genesis of his lectures-setting forth very graphically how they are formed from the paragraphs in his diary-all of which have been written out of the fulness of what has been at the time in his own mind and heart. These lectures are not logical in their method but rather poetical. Mr. Hawthorne was portrayed in his own loved twilight-the novelist with a style unsurpassed by any American-himself pure and clear, but loving obscurity and retirement, as if a mantle of darkness had been let fall upon him by his ancestors. He loves to keep his characters and sometimes even the plot of his story dwelling with him, in the sweet seclusion of his own gray mist.

Henry Thoreau was brought forward as the man who never yielded before any obstacle, who shunned no danger, cared not for ease or self-comfort, and who despite surroundings "found a way or made one." He first laid down his philosophy and compelled his life to march under its orders. Margaret Fuller was introduced as the first lady conversationalist in America, and one of New England's most charming writers-a true woman and at the same time a genius-genius in a man always combines womanly qualities with the manly, and in a woman combines manly qualities with the womanly. Of his own daughter Louisa M. Alcott, he spoke with very sweet and becoming modesty and tenderness, giving a view of her home life with her parents, sisters and friends, of the growth and culture of her native talent and of her career as an author. As we listened until toward midnight to the delightful flow of the conversation, now profound and vigorous, and again free and chatty, we were inclined toward the decision that the greatest of the "Concord Philosophers" was before us. As the company was dispersing some of those who were slow to part 
with such pleasant discourse sought out the information that Mr. Alcott would remain another evening in our city. Accordingly on Wednesday evening a few of the college students leading in the matter, Mr. Alcott was called upon and kindly consented to lead another conversation on "Heredity." Again the spacious parlors occupied the evening before were thrown open, and again the hours passed away in invigorating flow of thought and interchange of sentiment. Each community, said Mr. Alcott, has something peculiar to itself, something which has been forming throughout its whole existence, however long that may have been. A New England community is not just like a western community, nor are two New England communities just alike. Each family has something that is distinctively its own, perhaps a heritage of generations. Each individual has his own distinctive traits, some part of which he doubtless received from his ancestors-and it is sometimes hard to tell, as the individual lives and acts, how much of that life and of these actions are his own and how much are the out-speakings of some long since buried ancestor. A man may try to direct his life in one way, but he may have at every step to contend against the transmitted disposition of a grandfather or grandmother, even to remote generations. We do not fully know a man until we know not only what he does but also how much he is aided or is hindered by his ancestors. How far then is the individual responsible-certainly not for what was bestowed upon him without his own asking and for what remains without his welcome, was the position taken, but only for what he himself sanctions and wills.

Here ensued a long general conversation on man's responsibility, many of those present taking part in the unfoldment of the subject, which gradually drifted toward the question, how a man's own struggles with the evil about him and the evil tendencies within him affects his own nature and his strength and purity. He who is not at all tempted, when submitted to the common ordeals of life, certainly is on a higher plane than the one who is tempted by every untoward circumstance. But he who is being tempted resists, has a strength which the one who yields knows not, and which increases as the days and years go by.

Thus the conversation followed freely until the night was far advanced and we remembered that an early train must bear our teacher to other scenes. ${ }^{36}$

The parallel account in the Mt. Pleasant Journal deals chiefly with the lecture on "Heredity" since the reporter had not been present for the first conversation. ${ }^{37}$ But a few additional details fill out the picture. The writer definitely identifies Alcott's remarks with the Darwinian theory and presents

${ }^{36}$ The Free Press, Thursday, March 31, 1881.

${ }^{37}$ Mt. Pleasant Journal, Thursday, March 31, 1881. 
a more conservative account of the remarks. But of value is his description of Alcott the dialectician.

In the conversation which followed and the impromptu debate, Mr. Alcott showed himself at his best. It was in this open field of inquiry that his strength was most apparent. No question seemed to confuse or surprise him.

Alcott also found time during this stay to visit the public schools because of his life-long concern with education and educational methods. But he does not seem to have made a special appearance at Iowa Wesleyan University. The students shared the Wednesday evening conversation at Dr. Cole's home.

It is not a matter of surprise, therefore, that the Mt. Pleasant Journal on Thursday, March 8, 1888 gave full coverage to Alcott's death, which occurred almost simultaneously with that of Louisa M. Alcott. "His visit to Mt. Pleasant some eight years ago is vividly remembered by every school child then in our schools, which he visited and where he told with pardonable pride of his gifted daughter."

These two visits of Alcott to Mt. Pleasant had the preparation of a receptive, educated group of persons whose interests were similar. They resulted in a continuing influence upon the community and at least one concrete result in the work toward the establishment of the Public Library. Alcott's greatest contribution to his listeners was the stimulation of their own reading and a desire to spread informed, critical thought on all matters of importance.

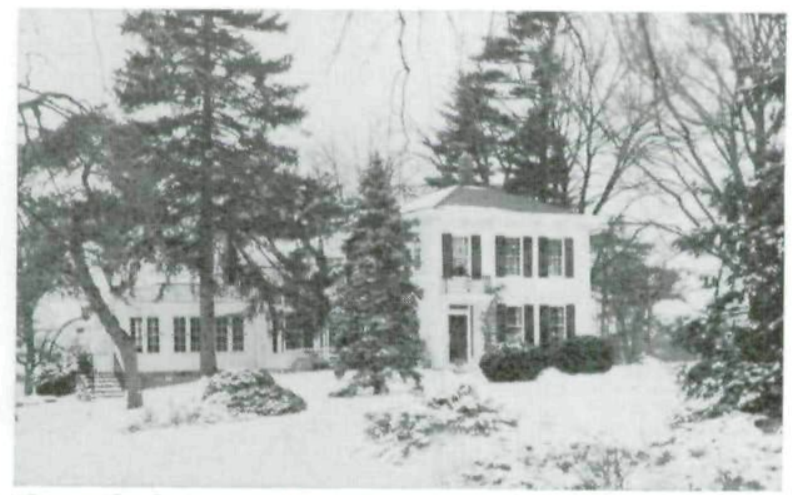

Today the Cole home in Mt. Pleasant is the residence of the Baron Crane family. 


\section{KEOKUK}

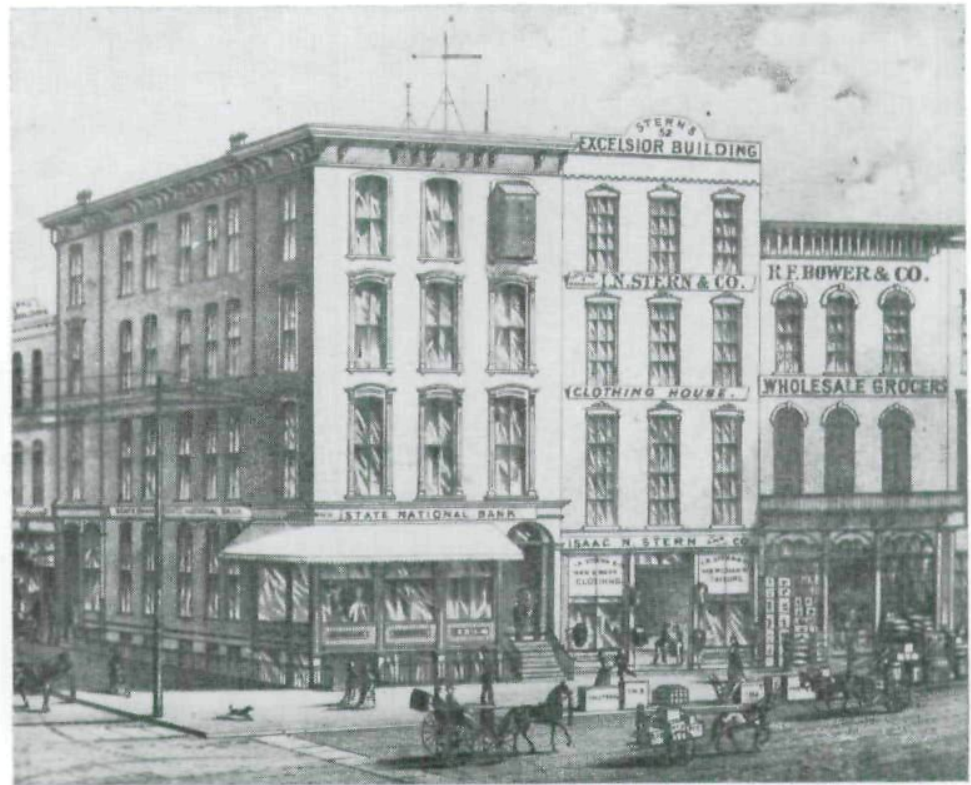

Andreas' Atlas of Lee County

1874 street scene in Keokuk.

Bronson Alcott visited Keokuk on January 29-February 2, 1873 after his stay in Mt. Pleasant and a shorter excursion to Burlington. This was promoted by Mr. S. M. Clarke, the editor of the Daily Gate City, with the sponsorship of the minister and leading laymen of the Unitarian Church. Unitarianism as an off-shoot of New England Transcendentalism provided a common area of interest. In Keokuk, as in other Iowa cities, the Unitarian or Universalist groups were frequent sponsors of Alcott's appearances. ${ }^{38}$ Alcott's friendship with Dr. and Mrs. W. R. Cole of Mt. Pleasant seems to have developed from mutual Unitarian connections.

News of the lectures in Mt. Pleasant and Burlington

${ }^{38}$ January 8, 1871; January 5, 1873; January 20, 1875 at the Davenport Unitarian Church: November 24, 1871; December 1, 1871 at the Dubuque Universalist Church. Cf. Hoeltje, op.cit., p. 379, 382, 388, 390. Cf. also Charles E. Snyder, "Unitarianism in Iowa," The Palimpsest, XXX (November, 1949), 347-348. 
trickled into Keokuk which had not been on the planned itinerary. A news story in the Daily Gate City on Saturday, January 25, 1873 demanded, "Why can't we have him here in Keokuk? . . . we know Keokuk can afford it and furnish a company that will delight to hear him." The article ended with a specific call to action. "If there are any of our citizens who want to make it their business to try to get Mr. Alcott to visit us, let them meet at our (Gate City) office at 11 o'clock this morning, to talk it over and decide the matter at once."

Apparently action was taken for the Daily Gate City on Wednesday, January 29 carried a news article with a series of quotations from Bronson Alcott and a description of the conversazione method. It concluded with the comment that "we shall be much disappointed if all who attend Mr. Alcott's . conversations do not find them not only a present pleasure, but a permanent advantage in the subjects discussed."

Alcott's visit was quite extended. He made four evening conversation appearances at private homes. ${ }^{39}$ His topics were selected from his usual repertoire. On Wednesday, January 29 he spoke to a small group on "Character" at the home of Dr. Freeman Knowles; on Thursday, January 30 on "New England Authors" at the home of Mr. E. H. Harrison; on Friday, January 31 on "Culture" at the home of Mr. Charles P. Birge; and on Saturday, February 1 at the home of Colonel C. H. Perry on "The Ideal Home." Sunday, February 2, he preached twice at the Unitarian Church at 11 a.m. and 7:30 p.m., by invitation of the minister, E. C. S. Browne, on the topic of "The Ideal Church" and also addressed the Sunday School. ${ }^{40}$

Here again was a tight knit group of substantial Keokuk citizens who were also leaders of the Unitarian Church. A brief account of this congregation and its laymen demonstrates how necessary such common interest was to a successful visit by Alcott.

The Unitarian Church of Keokuk, organized in 1853, erect-

${ }^{39}$ The Daily Gate City, Thursday, January 30, 1873; Friday, January 31, 1873 (two items); Saturday, February 1, 1873.

${ }^{40}$ The Daily Gate City, Sunday, February 2, 1873. 


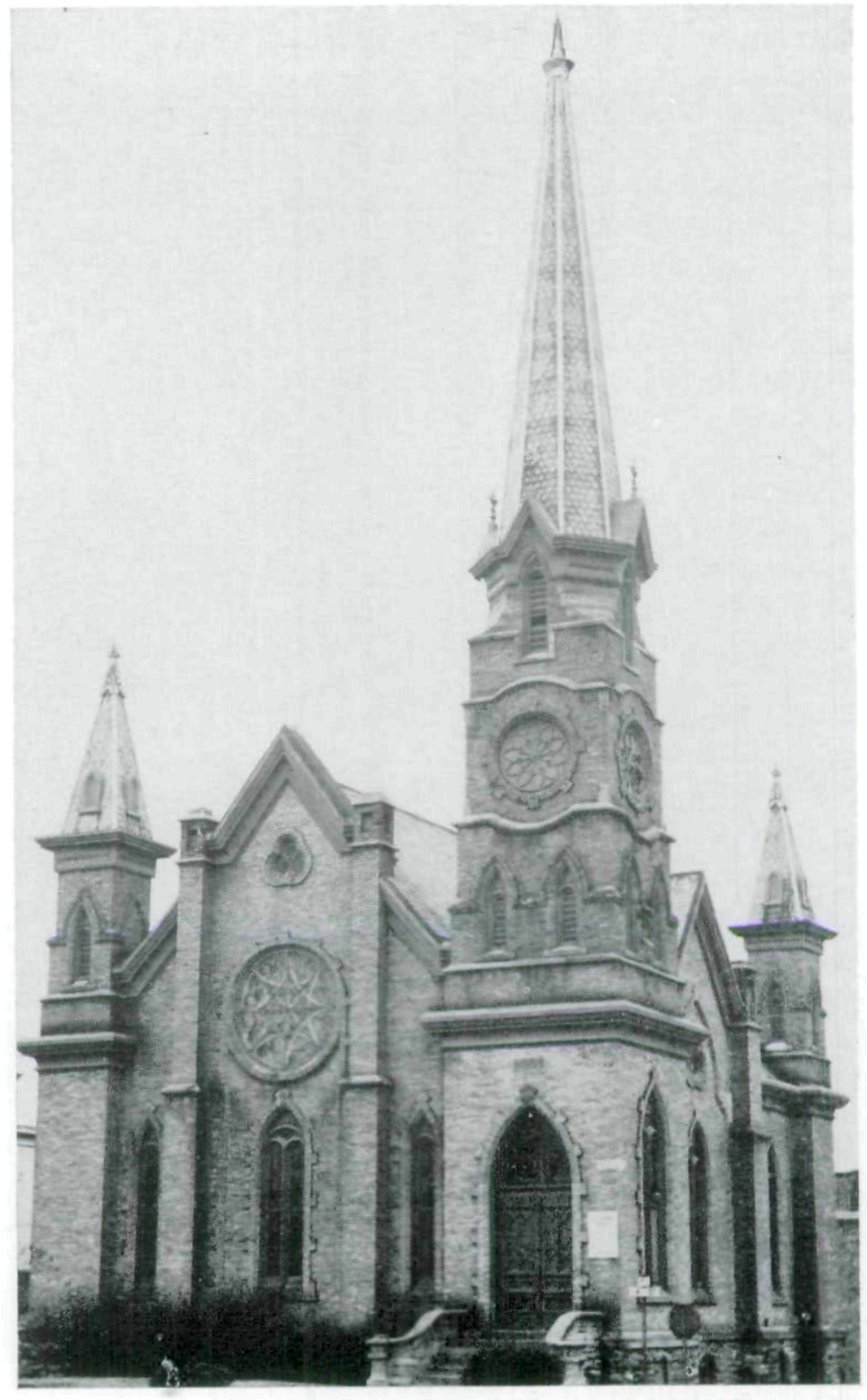

Courtesy Keokuk Daily Gate City

Old Unitarian Church in Keokuk where Alcott preached during his visit. 
ed a building in $1856 .{ }^{41}$ It was at the peak of its strength in 1871-1874 during the pastorate of E. C. S. Browne, for a new church was built in 1874 at a cost of $\$ 28,000$ with an organ listed at $\$ 2,000{ }^{42}$ The Unitarian organization was in a healthy condition at this time to take leadership in the visit of Alcott.

The four men whose homes were the scenes for the conversations were important citizens as well as Unitarian leaders. Dr. Freeman Knowles, a retired physician, had been in medical practice in Keokuk since the 1850 's and earlier in West Point, Iowa. ${ }^{43}$ He was one of the founders of the Keokuk congregation and later was the first president of the Iowa Unitarian Association.

Mr. E. H. Harrison served as an Alderman from Ward I and was a director of the State National Bank of Keokuk. ${ }^{44}$ In $1855 \mathrm{Mr}$. Harrison sold the land to the Unitarian congregation, but in 1864 presented his church with a sizeable donation to clear the mortgage. ${ }^{45}$

Mr. Charles P. Birge was president of Kellogg, Birge \& Company, wholesale grocers established in Keokuk since 1856; Vice President of the Keokuk Savings Bank and of the Citizens' Association. ${ }^{46}$ As early as 1866 he had taken leadership in the Keokuk Library Association and was an active layman in the Unitarian Church. ${ }^{47}$

Colonel C. H. Perry, with Dr. Freeman Knowles, had been one of the founders of the Unitarian Church and was long President of the Keokuk Library Association. ${ }^{48}$

${ }^{41}$ Story of Lee County, Iowa, edited by Nelson C. Roberts and S. W Moorhead (Chicago: S. J. Clarke Publishing Company, 1914), p. 329.

${ }^{42}$ History of Lee County, Iowa (Chicago: Western Historical Company, 1879), p. 646.

${ }^{43}$ History of Lee County, Iowa, op.cit., p. 646; Story of Lee County, Iowa, op.cit., p. 310.

${ }^{44}$ Holland's Keokuk City Directory, 1873-4 (Keokuk: Wister Publishing Company), II, 28, 57.

${ }^{45}$ History of Lee County, Iowa, op.cit., p. 646.

${ }^{46}$ Holland's Keokuk City Directory, op.cit., p. 36, 48, 49.

${ }^{47}$ Gate City Annual Trade Review, 1893, p. 7; Gate City Trade Supplement, January 1889 , p. 36.

${ }^{48}$ History of Lee County, Iowa, op.cit., p. 646; Holland's Keokuk City Directory, op.cit., p. 35. 


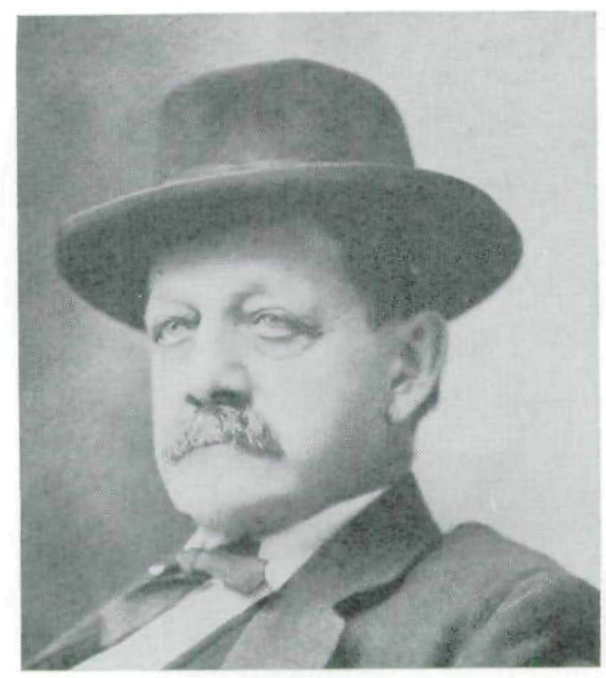

Charles P. Birge

Since Mr. S. M. Clarke, editor of the Daily Gate City, had been the moving spirit in the arrangements, lengthy and glowing accounts of the conversations appeared in the newspaper. Mr. Clarke did not personally attend the first gathering because "it was not generally known that Mr. Alcott would hold a conversation last evening." 49 But a full report of the lecture on "New England Authors" was made the next day. ${ }^{50}$

It was indicated in this and other Keokuk news items that a fee of fifty cents a person was charged for attendance. This was the common practice and the standard amount charged in other Iowa cities, since Alcott made these tours partly to replenish the family finances. ${ }^{51}$ There was no reference, however, to a fee at any of the Mt. Pleasant appearances either in 1873 or 1881 . One would suspect that Dr. William R. Cole personally took care of the expenses and honoraria on those occasions.

An account on Friday, January 31 was almost a column in

49 The Daily Gate City, Thursday, January 30, 1873.

${ }^{50}$ The Daily Gate City, Friday, January 31, 1873.

${ }^{51}$ Hoeltje, op.cit., p. 387. 
length with descriptive details about Alcott and the Alcott home as well as a full resume of Alcott's conception of Christianity. It was a curious bit of journalism; for the writer announced in the final paragraph that he had misinterpreted some of Alcott's opinions, revised his statements, but printed the full story!

On the day following Alcott's departure, Tuesday, February 4, the Daily Gate City ran a re-write in which all four conversations as well as the two Sunday sermons on "The Ideal Church" were recorded. Of particular interest was the tribute paid to Alcott's conversational skill.

Well, go and hear him and surrender at discretion. For he will subjugate you, inevitably. How your undigested opinions, your intellectual crudities fall away to dross in the alembic of his high, pure thought. $\mathrm{He}$ is an inspiring and inspired intelligence, a beautiful soúl. You cannot think of his impracticalities, of his heresy, in his presence. His clear thought masters you; his saintly spirit holds you. Unpretentious as a child, with unfailing amiability, a constant courtesy that flows from the depths of his nature accessible to everyone, with the genuine humility of wisdom, of kinship with Plato, but a Christian saint, uttering all the time with crystal clearness high and deep things, that deserve record just as they fall from his lips and would rank with the choicest of our literature, he deserves the high place which the cultivated minds of this country and Europe have accorded him.

Here certainly is a tribute to the paradox of Alcott - the meagre unimpressiveness of his published writings but the tremendous impact of his personality.

Traces of his visit continued in the press. On February 5, 1873 the Daily Gate City included an item on Margaret Fuller with a quotation about her from Bronson Alcott's Concord Days; and on Thursday, February 13 in a lecture at the Unitarian Church, Colonel Leighton "said at the outset that it was only a conversation a la Alcott ...” From Mt. Pleasant on February 21 came the report: "Keokuk has gone Alcottmad. The Unitarian minister preaches a sermon about his visit and calls it the 'Week on Parnassus'.",

It may have been a Week on Parnassus, but memories can

${ }^{52}$ Henry County Press, Friday, February 21, 1873. 
be short. When Alcott died in 1888, two Keokuk newspapers carried obituaries which neglected to state that Alcott had visited the city in $1873 .{ }^{53}$

\section{BURLINGTON}

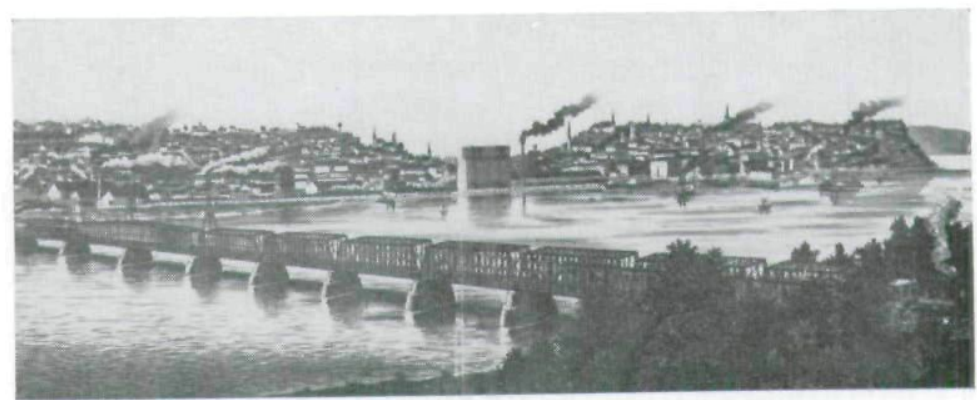

1890 view of Burlington from the Illinois shore.

Between the visits to Mt. Pleasant and Keokuk, Bronson Alcott spent four days in Burlington from Tuesday, January 21 to Friday, January 24 . He was the guest of the Honorable and Mrs. John H. Gear who had some previous acquaintance with him. But he made only two appearances, one at the home of Mrs. Gear for a select group and a lecture at the Public Library open to the general public at a fifty cent fee. This lecture did not attract very much attention. In fact the visit to Burlington made very little splash in the newspaper or public mind, and the reporting gave little indication of who Amos Bronson Alcott was. There seemed to be lacking in Burlington any group of persons with common interests who were aware of Alcott and prepared to welcome him to the community. The sponsorship was private $r$ a the $r$ than public. He was not the guest of a Reading Circle or Discussion Club as he had been in Mt. Pleasant and other Iowa communities, ${ }^{54}$ and there was no organized Unitarian Church there at the time. A Unitarian group had functioned from 1840-1850, but was non-existent in $1873 .^{55}$

${ }^{53}$ Keokuk Daily Constitution, Tuesday, March 6, 1888; Daily Gate City, Wednesday, March 7, 1888.

${ }_{54}$ Hoeltje, op.cit., p. 376, 381, 389, 390.

${ }^{55}$ Iowa File-Burlington-Churches in Burlington Public Library. 
The first newspaper notice on Sunday, January 19, stated:

Mr. Bronson Alcott, we are glad to learn, will give one of his delightful entertainments, next Tuesday evening, at the residence of Mr. J. H. Gear. The occasion will be one of great interest and benefit. ${ }^{56}$

Although the story was given a small headline "Conversationes", a peculiar linguistic invention, there was really nothing in the story to indicate whether Bronson Alcott lectured, sang or gave bird imitations. On Tuesday, January 21, the newspaper had a brief sentence - "Mr. Alcott will give his reading at Mrs. Gear's, this evening." ${ }^{\prime 7}$ This was even less informative.

A public lecture, however, was arranged for Friday night and the Thursday news account was a bit fuller.

Mr. Alcott will give one of his "Conversations" at the Public Library Rooms, to-morrow, Friday evening at $7 \frac{1}{2}$ o'clock. The subject, "New England Authors", is one which, from his long and varied acquaintance with eastern literary men, Mr. Alcott is specially able to handle. ${ }^{58}$

The Friday issue of the paper included a sentence story which drew attention to a paid advertisement.

Mr. A. Bronson Alcott, of Concord, Massachusetts, will hold a CONVERSATION

at the rooms of the Public Library, on Friday evening, Jan.

24 th, at $7 \frac{1}{2}$ o'clock.

SUBJECT: NEW ENGLAND AUTHORS

Persons desiring tickets can obtain them at the store of $\mathrm{Mr}$.

Wesley Jones. Price of tickets fifty cents. ${ }^{59}$

This was the final notice. There was no newspaper account of the lecture itself and no further reference to the visit. If it did make any impact upon the citizens of Burlington, the Hawkeye failed to note it.

There is no indication of what group sponsored the visit or arranged for the appearances. Only two names appear in the news stores: Mrs. J. H. Gear, his hostess, and Mr. Wesley Jones at whose store tickets were sold.

John H. Gear came to Burlington in 1843 and by 1867 was

${ }^{56}$ Burlington Hawkeye, Sunday, January 19, 1873.

${ }^{57}$ Burlington Hawkeye, Tuesday, January 21, 1873.

${ }^{58}$ Burlington Hawkeye, Thursday, January 23, 1873.

${ }^{59}$ Burlington Hawkeye, Friday, January 24, 1873. 


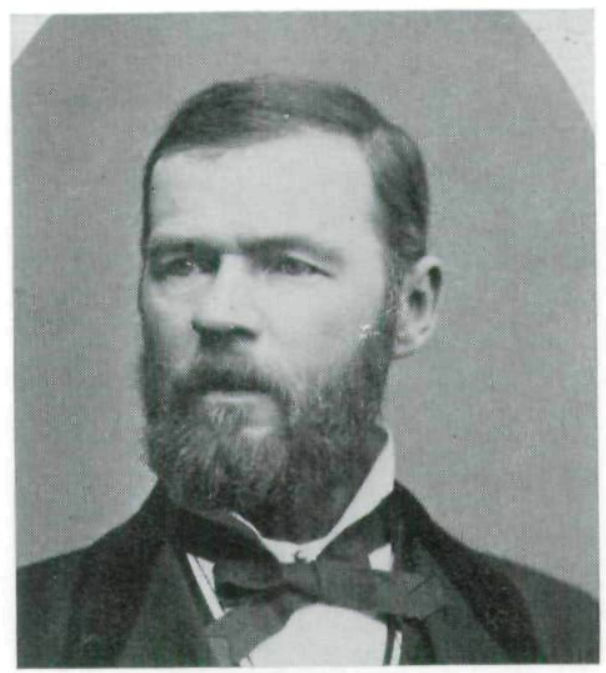

JOHN H. GEAR

President of the Burlington, Cedar Rapids and Minnesota Railroad with interests in the Burlington and Southwestern Railroad and the Burlington and Northwestern NarrowGauge Road. ${ }^{60}$ In 1871 he was a Republican member of the House of Representatives of the 14th General Assembly of Iowa, served as Speaker of the House in 1873 and 1875, and became Governor of Iowa in 1877. His wife, Harriet S. Foot of Middlebury, Vermont, married Mr. Gear in 1852. She had previous New England connections through which she might have developed a friendship with Alcott. But there are no easily available historical records to indicate why more was not made of the Conversation at the Gear home.

Mr. Wesley Jones was the proprietor of a sizeable business establishment. Born in Springfield, Ohio, he came to Burlington as a journalist in 1841. By 1866, he had purchased the bookstore of J. L. Case and operated a five story building at Third and Jefferson. ${ }^{61} \mathrm{He}$ was grandly described in the 1873

${ }^{60}$ The History of Des Moines County, Iowa (Chicago: Western Historical Company, 1879), pp. 636-637.

${ }^{61}$ A. T. Andreas, An Illustrated Historical Atlas of Des Moines County, Iowa (Chicago: 1873), p. 24; Portrait and Biographical Album of 


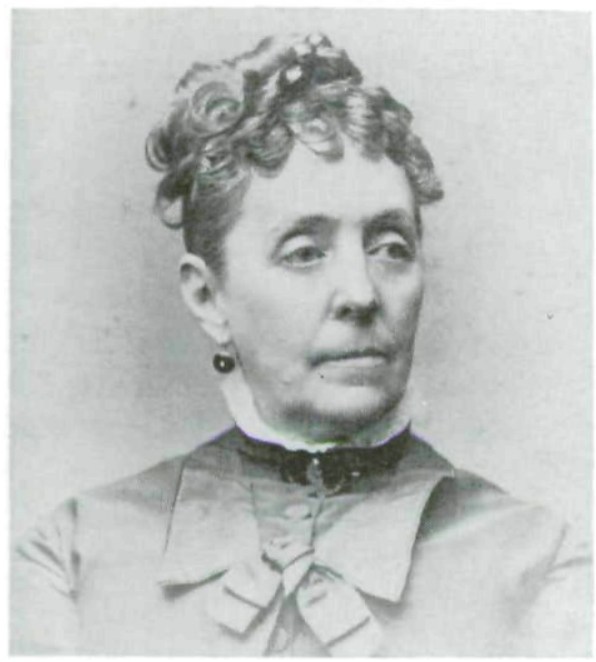

Harriet S. Gear

Historical Atlas of Des Moines County as “. . . the proprietor of the largest book and paper store owned and controlled by any one man on this continent and at the same time the youngest in years." ${ }^{\prime 2}$

The sale of tickets at Mr. Jones' store may have been just a business arrangement. At any rate, Mr. Jones had other things on his mind; three days after the lecture, Monday, January 27, he left for New York City on his spring buying trip. ${ }^{63}$

But a final complication was the fact that Burlington had other rival attractions. There was the well-publicized, subscription lecture series called The Starr Course; and the very Monday after Bronson Alcott spoke, Dr. Washington Gladden, the popular American clergyman and platform orator, was scheduled to appear on this forum. Advance notices in the newspaper were competing with the very announcements of Alcott's visit. ${ }^{64}$ That this was the event to be promoted was

Des Moines County, Iowa (Chicago: Acme Publishing Company, 1888), pp. 247-248.

${ }^{62}$ A. T. Andreas, op.cit., p. 24.

${ }^{63}$ Burlington Hawkeye, Monday, January 27, 1873. 1873.

${ }^{34}$ Burlington Hawkeye, Friday, January 24; Monday, January 27, 
more than evident from the full newspaper review of Gladden's lecture on the following day as contrasted with the lack of coverage for Alcott. ${ }^{65}$ It was bad timing together with little planning and the lack of a ready-made group prepared and eager to listen to the New England seer.

There is a vague reference in the previous study of Alcott's Iowa tours to a stop in Burlington in 1881 at the time of his second visit to Mt. Pleasant, ${ }^{6 B}$ but there are no newspaper references to such a visit in the Burlington press. At the time of the death of Alcott in March 1888, there was not even an obituary of the man in the Burlington papers, in striking contrast to the items in the Mt. Pleasant and Keokuk journals.

As one assesses the lectures of Alcott in southeast Iowa with others previously examined in the northern cities of the state, one can agree with the historian that "In the history of Iowa lecturing, certainly no speaker more thoroughly won the affection of his listeners" ${ }^{67}$ Alcott brought middlewestern readers to a first hand enthusiasm for the New England writers, stimulated thought on ethical matters, and gave purpose to scores of reading clubs and discussion groups which were the life-blood of the cultural life of the towns and cities of the area. ${ }^{68}$

${ }^{65}$ Burlington Hawkeye, Tuesday, January 28, 1873.

${ }^{66}$ Hoeltje, op.cit., p. 390.

${ }^{67}$ Ibid., p. 392.

${ }^{68}$ Shepard, op.cit., p. 487. 
Copyright of Annals of Iowa is the property of State of Iowa, by \& through the State Historical Society of Iowa and its content may not be copied or emailed to multiple sites or posted to a listserv without the copyright holder's express written permission. However, users may print, download, or email articles for individual use. 